\title{
Bloom's taxonomy and goals of traditional education system insight from Ayurveda
}

\begin{abstract}
Bloom's taxonomy classifies the goals of modern education system. It defines three domain of learning cognitive, affective and psychomotor domain, related with head, heart and body respectively. Ayurveda mentioned four qualities of physician in the form of chatushpada (quadruple), as to acquire knowledge, to gain practical knowledge and importance of cleanliness. Proposed review study was carried out to high light the concept of traditional education system designed by Acharya Charaka, Sushruta and Vagbhata to reflect goals of traditional education system. Classical texts (Samhita) of Ayurveda as Charaka, Sushruta, Ashtanga Sangraha and Ashtanga Hridaya were consulted as references to know the qualities of chatushpada. Literature available regarding modern Bloom's taxonomy was also collected. These references from both streams of knowledge were compared and analyzed critically. Literature search revealed that qualities of bhishak (physician) among chatushpada, includes the three domain of Ayurvedic education system. Paryavadatatva means having excellence in theoretical knowledge, bahushodrustakarmata means having extensive practical experience, dakshya means dexterity and shouch means cleanliness of mana (mind) and sharir (body). If physician endowed with these qualities leads to elimination of disorders. As Bloom's taxonomy classify the goals of modern education system, the four qualities of physician reflects the goals of traditional system of education in Ayurveda.
\end{abstract}

Keywords: Ayurved, bhishak, bloom's taxonomy, chatushpad
Volume I3 Issue 3 - 2020

\author{
Kalpana Tawalare, Kiran Tawalare \\ Department of Rachana Sharir, Maharashtra University of \\ Health Sciences, India
}

Correspondence: Kalpana Tawalare, Department of Rachana Sharir, Maharashtra University of Health Sciences, Bhausaheb Mulak Ayurved College, Buttibori, Nagpur, India,

Email drkalpanataalare@gmail.com

Received: May II, 2020 | Published: June 24, 2020

\section{Introduction}

Blooms taxonomy is set of three hierarchical models used to classify the goals of modern education system in to level of complexity and specificity to promote higher forms of thinking in medical education and to meet patient's expectations in medical profession. It defines three domains of learning as cognitive domain, affective domain and psychomotor domain. Cognitive domain concern with the knowledge, affective domain related with attitude, feeling and psychomotor domain is about doing. ${ }^{1}$

Ayurveda is an ancient system of medicine in India which means science of life. The broad goal of Ayurveda is to protect health of healthy person and alleviate the disorders of diseased person. This science is considered as discipline of Atharv veda. It is divided in eight branches. Bruhatrayee (Charak, Sushrut, Vagbhat samhita) and Laghutrayee (Madhavnidan,Sharangdhar, Bhavprakash samhita) are considered as a base of the life science. As a divine tradition Lord Brahma revealed this Ayurveda first time and then by generation to generation eventually it passes on to terrestrial tradition Dhanvantari (shalya pradhan ,1500 BC) and Punarvasu Atreya (Chikitasa pradhan, $1000 \mathrm{BC}$ ). Charak samhita is chikitsa (medicine) oriented text. The present text of Charak samhita read all over world is the basic Agnivesh tantra refined and enlarged with annotation by Charaka and redacted by Drudhabala.

In ancient system of medicine adhyayan (study), adhyapan (teaching) and tadvidsambhasha (healthy discussion) were the means for acquiring knowledge. ${ }^{2}$ In that era near about 500 BC Acharya mentioned the qualities of good physician in the form of chatuspada (quadruple) as paryavadatatva (excellence in theoretical knowledge), bahushodrustakarmata (extensive practical experience), daksha (dexterity) and Shouch (cleanliness). ${ }^{3}$ As Bloom's taxonomy defines the goals of education system, likewise qualities of bhishaka among chatushpada could define the goals of ancient education system. Thus study was proposed to highlighten the concept of traditional education system designed by Acharya to reflect the goals of traditional education system.

\section{Aim and objective}

To highlight the goals of traditional education system insight from Ayurveda.

\section{Material and methods}

Classical texts of Ayurveda viz. Charaka Samhita, Sushruta Samhita, Ashtanga Sangrah and Ashtanga Hridaya were consulted as research references for ancient study of education system described in that era. Literature available regarding Blooms taxonomy was also collected. These references from both streams of knowledge were compared and analyzed critically.

\section{Result and discussion}

Qualities of bhishak (physician) among chatushpada, includes the three domain of Ayurvedic education system. First quality paryavadatatva means having excellence in theoretical knowledge, second bahushodrustakarmata means having extensive practical experience, third dakshya means dexterity and fourth shouch means cleanliness of mana (mind) and sharir (body). If physician endowed with these qualities leads to elimination of disorders. Bloom's 
taxonomy of cognitive domain explains the level as knowledge, comprehension, application, analysis, synthesis and evaluation. ${ }^{4}$ The simplified levels of cognitive domains are knowledge means mastery of subject. Comprehension means understating information and translation knowledge into new context. Application means use of information and methods in new situations. Similarly in Ayurveda, if we define the level of paryavadatatva the first level is shastra means excellence in theoretical knowledge. If the physician devoted to shastra means scripture, knowledge. Second level is shastraarth means understanding the meaning or interpretation of scripture. Third level is vidnyanepravrutto means application of knowledge. Forth level is karmadarshane means with practical experience, are the qualities of bhishak with which he can promotes the life. ${ }^{5}$ This reference reveals that, the ancient education system has knowledge of values of cognitive domain (Table 1).

Table I Cognitive domain simplified levels and qualities of paryavadatva bhishak

\begin{tabular}{|c|c|}
\hline Cognitive domain & Paryavadatva bhishak \\
\hline I. Knowledge - mastery of subject. & I. Shastra - knowledge scripture \\
\hline 2. Comprehension - understanding of information & 2. Shastraartha - understanding the meaning of scripture \\
\hline $\begin{array}{l}\text { 3. Application - use of information into new } \\
\text { context }\end{array}$ & $\begin{array}{l}\text { 3. Vidnane pravritti - application of knowledge } \\
\text { 4. Karmadarshan - apply knowledge in } \\
\text { practice }\end{array}$ \\
\hline
\end{tabular}

Affective domain is focused on development of attitude, beliefs and values. Affective learning is about gaining new perception as responsibility and personal relation. Bloom's taxonomy of affective domain explains the level as receiving, responding, valuing, organising and characterization. ${ }^{6}$ The simplified level of affective domain are receiving means passively attending to certain stimuli. Responding means compliance to given expectation by reacting to stimuli. Valuing means accept the worth of things. Organisation means determines interpretation. Characterisation means integrate some value into total philosophy of life or world view. In Ayurveda, it is described that second quality of bhishak is shouch means cleanliness of mana (mind) and sharir (body). Acharya had given measure emphasis on behaviour of bhishak in the form of vaidyavritti. Acharya Charaka mentioned the first level as maitri means co-operative and friendly behaviour. Second level is karunya aarteshu means extending compassion towards the diseased. Third level is shakya priti means assume responsibility in curable disease and forth level is upekshanam prakrutishtheshu means make a decision to avoid the incurable disease (Table 1). ${ }^{7}$ In the same context of qualities of vaidya required in good practises are sumanasa means good minded, kalyanabhiharen means wishing good for all and did and susahayavat means stay always ready to help. These references from classical text of Ayurveda realises that in ancient system of education, behaviour of doctor is also counted in destiny, as in affective domain of Bloom's taxonomy (Table 2).

Table 2 Affective domain and qualities of shouch

Affective domain
I. Receiving - attending stimuli passively
2. Responding - compliance to given expectation by
reacting stimuli
3. Valuating - accept the worth of things, assume the
responsibility
4. Organisation - forms judgement, determines inter
relationship

Third is psychomotor domain. Its relevant verbs have been less well articulated than cognitive and affective domains at all levels of educations. ${ }^{8}$ However it is important area which mentioned the goals of education system related with skills of course. The level of psychomotor domain involves physical movement and coordination as imitation, manipulation, precision, articulation and naturalisation. Imitation means observing skills. Manipulation means performs skill according to instruction. Precision means reproduce skills with accuracy, proportion and usually perform skill independently. Articulation means combine one or more skill in consistency. Naturalisation means complete one or more skill with ease. In Ayurveda third quality of bhishak is bahushodrustakarmata means having extensive practical experience; forth quality is dakshya means dexterity. In Ayurveda, Acharya Sushruta had given the importance to practical approach as he was a surgeon. He mentioned that, to be

\section{Shouch (Sharir, mana)}

I. Maitri - cooperative and friendly behavior

2. Karunya arteshu - extends compassion towards diseased

3. Shakya priti - assume responsibility in curable disease

4. Upekshanamprakritisthiteshu - take farm judgement to avoid the incurable disease

fit in surgical practices one should acquired theoretical knowledge with practical experience. ${ }^{9}$ For that purpose he specially mentioned yogya vidhi ${ }^{10}$ means first to practice on dummy things and then $\mathrm{g}$ text interpreted it to develop idea. Third level is drustkarmana means observe the action and performs the skill as per advice. Fourth lev o for real surgery. In this concern of psychomotor domain he mentioned first level adhigat tantra means complete the study of text to pursue the idea. Second level is upasit tantrarthen means understand the meaning of el is krutyogen means made fit our self to practice independently that is proficiency. Fifth level is shastra nigadata means decapitation of teaching of science always (Table 3). ${ }^{11}$ These guidelines show the importance of developing skills for vaidya is very necessary to become fit in practises. So as per the Bloom's taxonomy development of head, heart and hand is necessary for the medical student likewise paryavadatatva, bahushodushtkarmata and daksha, shouch for becoming vaidya is necessary. 
Table 3 Psychomotor domain and bahushodrustakarma bhishak

\begin{tabular}{ll}
\hline Psychomotor domain & Bahushodrustakarma bhishak \\
\hline I. Imitation - observes skill, tries to repeat it & $\begin{array}{l}\text { I. Adhigat tantra - complete study to pursue idea } \\
\text { 2. Upasittantraarth - understood and observe the interpretation }\end{array}$ \\
$\begin{array}{ll}\text { 2. Manipulation - perform skills according to instruction } & \begin{array}{l}\text { 3. Drushtakarmana - observed skill taught by guru and perform the skill } \\
\text { as per advice }\end{array} \\
\text { 3. Precision - reproduce skills with accuracy } & \text { 4. Krutyogyen - made fit our self by doing practice independently } \\
\text { 5. Proficiency - complete skill with ease (naturalization) } & \text { 5. Shastranigadata - decapitation of teaching of science always }\end{array}$ \\
\hline
\end{tabular}

\section{Conclusion}

As the Bloom's taxonomy classify the goals of modern education system in the form of cognitive, affective and psychomotor domain. The four qualities of physician paryavadatatva related with head, bahushodushtkarmata and daksha related with hand and shows is related with heart reflects the goals of traditional system of education in Ayurveda.

\section{Acknowledgments}

None.

\section{Conflicts of interest}

Author declares that there are no conflicts of interest.

\section{Funding}

None.

\section{References}

1. Bloom BS. Taxonomy of educational objectives. New York, USA: David McKay Company Inc; 1964.

2. Agnivesha, Charaka, Dridhabala, Charak Samhita, Viman Sthana, Rogbhishgjitiy Adhyaya, 8/6. In: Sharma PV, editor. Varanasi, 2011; p351.

3. Agnivesha, Charaka, Dridhabala, Charak Samhita, Sutra Sthana, Khuddagchatushpad Adhyaya, 9/6. In: Sharma PV, editor. Varanasi, India: Chaukhambha Orientalia; 2011. p. 62
4. Liu T, Zhong S, Wang B, et al. Similar profiles of cognitive domain deficits between medication-naïve patients with bipolar II depression and those with major depressive disorder. J Affect Disord. 2019;243:55-61

5. Agnivesha, Charaka, Dridhabala, Charak Samhita, Sutra Sthana, Khuddagchatushpad Adhyaya, 9/18, In: Sharma PV, editor. Varanasi, India: Chaukhambha Orientalia; 2011; p. 64

6. Stephens M, Ormandy P. Extending conceptual understanding: How interprofessional education influences affective domaindevelopment. $J$ Interprof Care. 2018;32(3):348-357.

7. Agnivesha, Charaka, Dridhabala, Charak Samhita, Sutra Sthana, Khuddagchatushpad Adhyaya, 9/26, edited by Sharma PV, Reprint ed. Chaukhambha Orientalia, Varanasi, 2011; p64

8. http://www.nwlink.com/ donclark/hrd/Bloom/psychomotor_domain. html

9. Sushruta, Sushruta Samhita, Sutra Sthana, Adyayansampradaniya Adhyaya, 3/47. In: Srikantha Murthy KR, editor. Varanasi, India: Chaukhamba Orientalia; 2008. p. 23.

10. Sushruta, Sushruta Samhita, Sutra Sthana, Yogyasutriya Adhyaya, 9/3. In: Srikantha Murthy KR, editor. Varanasi, India: Chaukhamba Orientalia; 2008. p. 57

11. Sushruta, Sushruta Samhita, Sutra Sthana, Vishikhanupraveshaniya Adhyaya, 10/3. In: Srikantha Murthy KR, editor. Varanasi, India: Chaukhamba Orientalia; 2008. p. 59. 